Journal of Education and Vocational Research

Vol. 1, No. 3, pp. 72-79, June 2011

\title{
Business and Accounting Students' Perceptions on Industrial Internship Program
}

\author{
Mohd Jaffri Abu Bakar, Rosmaria Jaffar Harun, Ku Naraini Che Ku Yusof, Izah Mohd Tahir* \\ Faculty of Business Management and Accountancy, University Sultan Zainal Abidin (UniSZA), 21300 Kuala \\ Terengganu, Malaysia \\ *izah@unisza.edu.my
}

\begin{abstract}
Internship programme is one of the methods which will expose students a chance to gain a deeper understanding of the knowledge that they have learned in the classrooms through actual works experience in the industry. Normally, before a student graduates, he/she has to undergo this industrial internship programme. The objective of this study is to examine business and accounting students' opinions on industrial internship programme by using a survey instruments which consists of 18 statements. The statements were grouped into four dimensions: Career; Knowledge and Practical Experience; Soft Skills; and Monetary and Non Monetary Incentives. The survey was conducted by using four point-likert scale and distributed to 33 business and 51 accounting students at University Sultan Zainal Abidin, Malaysia. The results indicate that both business and accounting students emphasise on Career as the most important dimension. Next of importance are Soft Skills, Knowledge and Practical Experience, and Monetary and Non Monetary Incentives. The results also indicate that both business and accounting students have similar opinions regarding industrial internship programme.
\end{abstract}

Keywords: Industrial Internship, Work Experience, Business and Accounting Students

\section{Introduction}

Many consider internship as an opportunity to integrate career related experience into an education (diplomas or undergraduates) by participating in planned and supervised work. Internship is works in a temporary position with an emphasis on the on-the-job training, usually for a fixed period of time. In a simple word, internship is work-related professional learning experiences that provides students with the actual working environment by placing them to work in organizations outside the university (Furco, 1996). In addition, the internship enables students to apply their knowledge on concept and theories that they had learned in class to actual practices in organizations. The organizations can be a profit or non profit oriented. Some internship are paid but many are not paid. Furco (1996) states "Interships programs engage students in service activities primarily for the purpose of providing students with hands-on experiences that enhance their learning or understanding of issues relevant to a particular area of study" (page 11).

University Sultan Zainal Abidin, one of the public universities in Malaysia, through Faculty of Business Management and Accountancy also incorporates a structured and compulsory 6 months (1 semester) industrial internship programme into Bachelor of Business Administration (BBA) and Bachelor of Accounting (BAC) curriculum. This industrial internship programme is compulsory and is equivalent to carry 12 credits hour. This internship programme is expected to give extra knowledge to students in the related industries of their studies, develop and enhance the requisite skills for effective interpersonal and group work and relationships, gain self-awareness, personal growth, maturity, independence and improve their marketability after graduation. BBA students will undergo this internship programme in their fourth year - second semester while BAC students in their fourth year - first semester.

This programme is coordinated by Faculty of Business Management and Accountancy under Department of Finance and Banking for BBA students and Department of Accounting for BAC students. Students will choose any institutions that are related to their studies especially financial institutions, audit firms, government institutions and selected private sectors. Since the programme was introduced in 2009, no research has been carried out to examine students' perceptions on the programme. Thus this research is carried out to examine the business and accounting students' perceptions on internship programme. 
This study aims at examining business and accounting students' opinions on internship programme. Specifically, the objectives are as follows:

- To examine the perceptions of business (BBA) and accounting (BAC) students towards industrial internship programme; and

- To investigate whether there were any significant differences in opinions (by course and gender) between BBA and BAC students on industrial internship programme.

The study answers following research questions based on the research objectives.

- What are the perceptions of business and accounting students on industrial internship programme?

- Are there any significant differences on the opinions (by course and gender) between BBA and BAC students on industrial internship programme?

The findings from this research give us an overview of the industrial internship programme from the students' perspectives. This would give some information to the faculty concerned on the emphasis placed by students with respect to dimensions such as soft skills and knowledge obtained from the programme.

\section{Literature Review}

Hauck et. al. (2000) examined the impact of structured internship programmes on students' performance in construction management curricula and found inconclusive results. This is because the results from two indicators of performance i.e. GPA (grade point average) and subsequent course performance contradicted each other. As a whole, the study found that the internship group outperformed the non-internship group but the difference between groups was not statistically significant. Further, the study also found that students' perceptions on the internship experience were positive. Muhammad et al. (2009) studied about the internship programme for accounting students from the interns' perspective. The objective of their study was to examine whether the expected benefits of internship were actually achieved. They found that from the interns' perspective, internship was not able to give them the expected benefits. However, the study also concluded that internship was regarded as successfully providing guideline to students in choosing the career path and enhancing knowledge of public sector accounting. Abdul-Karim (2009) conducted a survey on forty students from the Computer and Information Science Department in 2002 to evaluate their achievement in developing well-rounded graduates. The study concluded the following;

- Internship program is important to these students;

- Their 8-month industrial internship program is a success; and

- The role played by host companies is crucial in consolidating and dictating the kind of experience these students will undergo.

Divine e. al. (2006) analysed students' performance in an internship programme of 629 students in United States collected over a five-year time frame. They were evaluated by their internship supervisors on five attributes: reliability; interpersonal skills; communication skills; ability to handle stress; and attitude. Their study found that the key areas of improvement for the programme were communications skills followed by the ability to handle stress. In the previous research mentioned above, the internship experience is argued to be beneficial to the students, employers as well as the institutions. Knouse and Fontenot (2008) had discussed the various advantages in details. The benefits as reviewed by the authors are as follows:

- Enhanced employability;

- Realistic expectations of interns;

- Satisfaction with the internship experience;

- Internship prerequisites as predictors of internship success; and

Knouse and Fontenot (2008) also concluded that the internship experience can be improved in several ways, as follows:

- Active student participation in the process;

- Active employer participation in the process;

- Clear expectations;

- Change prerequisites to reflect the predictors more closely related to intern success; 
- Build mentoring into the internship program; and

- Keeping a journal

Thus the benefits of internship programme can be categorised into three groups; benefits to students, employers (corporations) and institutions/universities. Table 1 lists some of the benefits from this programme.

\section{Table 1: Benefits of intership programme}

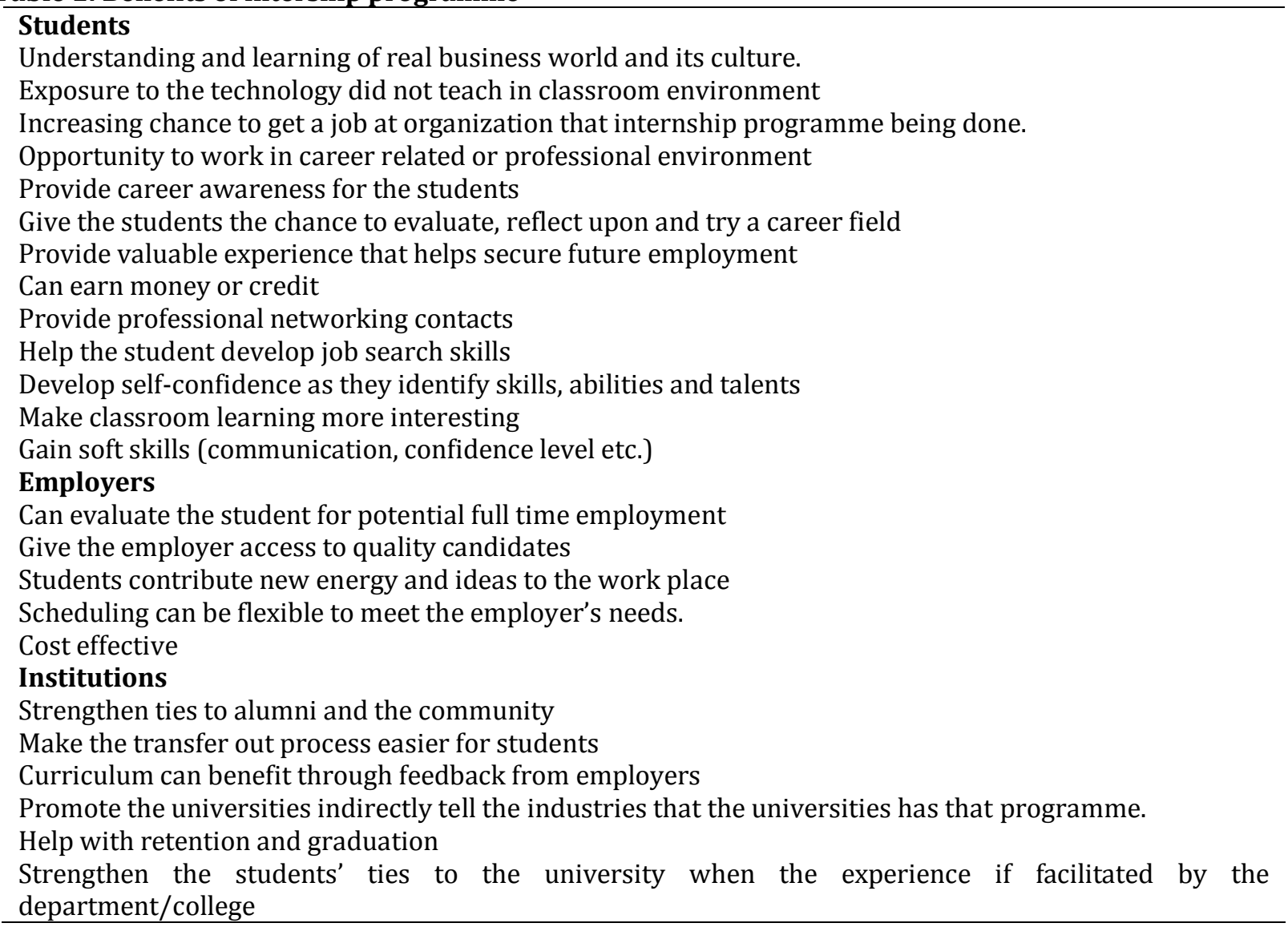

From the table, it shows that internship programme is beneficial to students, employers as well as institutions. Therefore, it is not surprising that many universities have incorporated this programme into their education curriculum. Thus, the importance of internship programme cannot be neglected. Further, understanding students' perceptions are also important. This could assist the department or the faculty in the university concerned, in understanding the needs and the benefits to the students.

\section{Data and Methodology}

This study is carried out to examine the opinions of BBA and BAC students on industrial intership programme. This research was undertaken at University Sultan Zainal Abidin, Malaysia. Questionnaires were based on previous research (Moore et. al. 2006; Abdul-Karim, 2009; Muhammad et. al. 2009), and distributed to $33 \mathrm{BBA}$ and $51 \mathrm{BAC}$ students There were two sections in the questionnaires; Section A is related to the demographic profiles of the respondents. Three items were examined; course, gender and performance (Cummulative Grade Point Average or CGPA). Section B is related to the responses made on 18 statements. These 18 statements were categorised under four dimensions: Career; Knowledge and Practical Experience; Soft Skills; and Monetary and Non Monetary Incentives. The statements were measured using a 4 -point scale with the following anchors: 1 = strongly disagree; 2 = disgree; 3 = agree; and $4=$ strongly agree. The questionnaires were distributed to BBA and BAC students before they actually went for their internship 
attachment. For BBA students, the programme began in December 2010 while for BAC students, the internship programme started in May 2011. SPSS software was employed to analyse the data.A frequency distribution was used to describe the sample. Mean and standard deviations of the statements were also computed. Finally, one-way analysis of variance (ANOVA) procedures were performed to the data set to test whether the mean of the students' opinions on industrial internship program differ by course (BBA and BAC) and gender (female and male).

\section{Findings}

Students' Profiles: A total of 84 students participated in this survey. Figure 1 depicts the profiles of the respondents. Accounting students (BAC) outnumbered business students (BBA), 60.7 percent and 39.3 percent respectively. Of these 82.1 percent are female and the rest (3.6 percent) are male. Majority of the students are doing quite well with Cummulative Grade Point Average (CGPA) of between 3.49 to 3.00 point (47.6 percent) and between 2.99 to 2.50 point (48.8 percent).

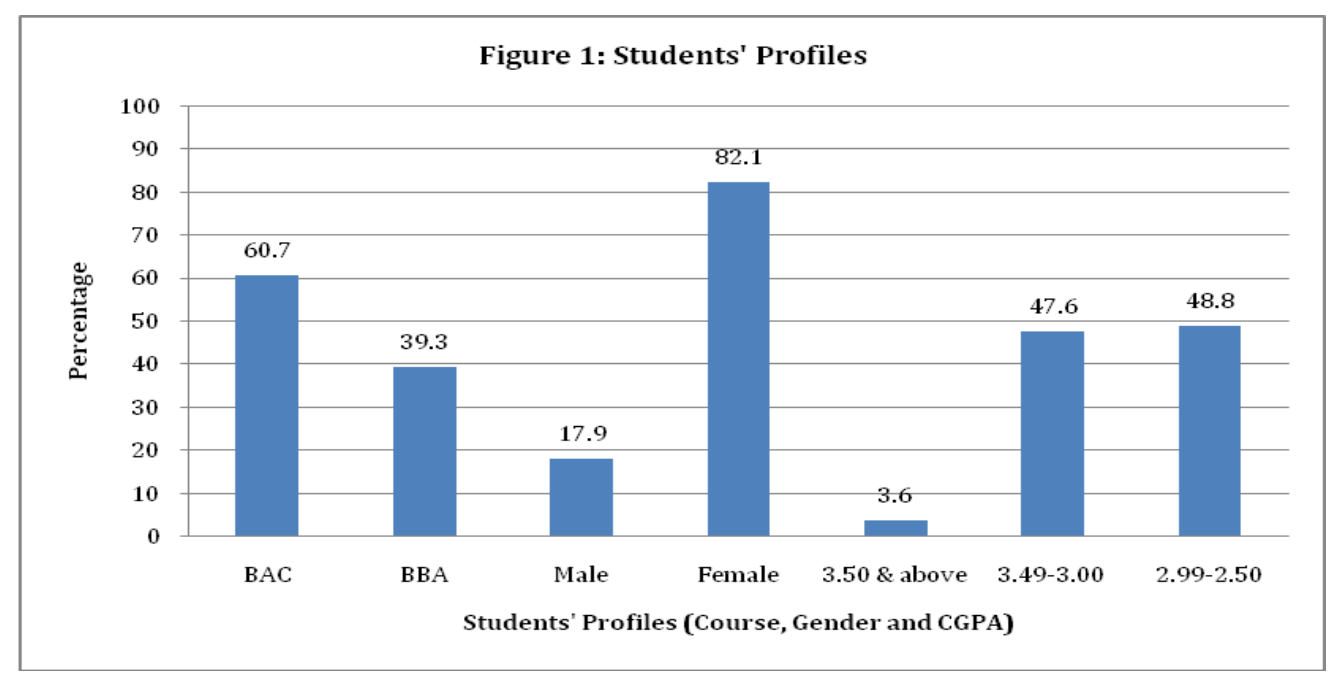

Summary of Responses: An analysis of the perceptions of BBA and BAC students towards internships programme is shown in Table 2.

The first dimension concerns with items related to Career. The highest mean score for BAC students is 3.69 relating to $\mathrm{S} 1$ "The internship experience is able to prepare me to be a better employee in the future", while BBA students chose S2, "The internship experience provides me with the relevant knowledge and practical experience to assist me in adapting myself to my future working environment". Looking at the overall scores (BBA and $\mathrm{BAC}$ ), the results indicate that the highest mean value is related to $\mathrm{S} 1$, "The internship experience is able to prepare me to be a better employee in the future".

For the second dimension (Knowledge and Practical Experience), BAC students choose S8 "The internship experience is able to expose me to the latest technology adopted in the work place" (Mean $=3.41$ ) wheareas BBA students choose S7 "The internship experience reinforce the knowledge I gain in the classroom", (Mean = 3.27). Overall scores show that both BBA and BAC students rate S8 "The internship experience reinforce the knowledge I gain in the classroom" (Mean $=3.33$ ), as the most important statement. 
Table 2: Descriptive Statistics on Perceptions of Internship

\begin{tabular}{|c|c|c|c|c|c|c|c|}
\hline \multirow[t]{2}{*}{ No. } & \multirow[t]{2}{*}{ Statements } & \multicolumn{2}{|c|}{ BAC } & \multicolumn{2}{|c|}{ BBA } & \multicolumn{2}{|c|}{ Overall Scores } \\
\hline & & Mean & S.D & Mean & S.D & Mean & S.D \\
\hline \multicolumn{8}{|c|}{ Career } \\
\hline S1 & $\begin{array}{l}\text { The internship experience is able to prepare me } \\
\text { to be a better employee in the future }\end{array}$ & 3.69 & 0.469 & 3.39 & 0.496 & 3.57 & .498 \\
\hline S2 & $\begin{array}{l}\text { The internship experience provides me with the } \\
\text { relevant knowledge and practical experience to } \\
\text { assist me in adapting myself to my future } \\
\text { working environment }\end{array}$ & 3.53 & 0.504 & 3.58 & 0.502 & 3.55 & .501 \\
\hline S3 & $\begin{array}{l}\text { The internship programme will provide me with } \\
\text { the necessary information and experiences to } \\
\text { choose the right career path upon graduation }\end{array}$ & 3.39 & 0.493 & 3.12 & 0.600 & 3.29 & .550 \\
\hline S4 & $\begin{array}{l}\text { The internship programme will provide me with } \\
\text { the necessary job experience that can improve } \\
\text { my chances to get a good job upon graduation }\end{array}$ & 3.45 & 0.541 & 3.18 & 0.683 & 3.35 & 611 \\
\hline \multicolumn{8}{|c|}{ Knowledge and Practical Experience } \\
\hline S5 & $\begin{array}{l}\text { The internship experience will help me to relate } \\
\text { the theories learned in the classroom to the work } \\
\text { environment }\end{array}$ & 3.20 & 0.601 & 3.00 & 0.661 & 3.12 & 629 \\
\hline S6 & $\begin{array}{l}\text { The internship experiences reinforce the } \\
\text { knowledge I gain in the classroom }\end{array}$ & 3.06 & 0.506 & 3.18 & 0.635 & 3.11 & .560 \\
\hline S7 & $\begin{array}{l}\text { The internship experiences help make my } \\
\text { educational experiences more relevant }\end{array}$ & 3.35 & 0.559 & 3.27 & 0.626 & 3.32 & 584 \\
\hline Soft & $\begin{array}{l}\text { The internship experience is able to expose me to } \\
\text { the latest technology adopted in the work place } \\
\text { Skills }\end{array}$ & 3.41 & 0.497 & 3.21 & 0.600 & 3.33 & .545 \\
\hline S9 & $\begin{array}{l}\text { Internship programme helps me to be physically } \\
\text { and mentally fit }\end{array}$ & 3.35 & 0.559 & 3.45 & 0.564 & 3.39 & .560 \\
\hline S10 & $\begin{array}{l}\text { The internship experiences will help me to } \\
\text { develop my problem solving skill }\end{array}$ & 3.31 & 0.469 & 3.52 & 0.508 & 3.39 & .491 \\
\hline S11 & $\begin{array}{l}\text { The internship experiences will help me to } \\
\text { develop my communication skill }\end{array}$ & 3.55 & 0.503 & 3.73 & 0.452 & 3.62 & .489 \\
\hline S12 & $\begin{array}{l}\text { The internship experiences will help me to } \\
\text { develop my interpersonal skill }\end{array}$ & 3.45 & 0.503 & 3.76 & 0.435 & 3.57 & .498 \\
\hline S13 & $\begin{array}{l}\text { The internship experiences will help me to } \\
\text { improve my personal confidence and self-esteem }\end{array}$ & 3.57 & 0.500 & 3.64 & 0.489 & 3.60 & .494 \\
\hline S14 & $\begin{array}{l}\text { The internship programme will help me improve } \\
\text { my English }\end{array}$ & 3.10 & 0.671 & 3.00 & 0.707 & 3.06 & 683 \\
\hline \multicolumn{8}{|c|}{ Monetary and Non Monetary Incentives } \\
\hline S15 & $\begin{array}{l}\text { The internship programme is able to give me the } \\
\text { opportunity to work in a team }\end{array}$ & 3.35 & 0.522 & 3.18 & 0.528 & 3.29 & .528 \\
\hline S16 & $\begin{array}{l}\text { The internship programme is able to give me the } \\
\text { opportunity to earn some money }\end{array}$ & 2.94 & 0.732 & 2.42 & 0.830 & 2.74 & .808 \\
\hline S17 & $\begin{array}{l}\text { The internship programme is able to give me the } \\
\text { opportunity to build up rapport and networking } \\
\text { with people in the industry and business arena }\end{array}$ & 3.27 & 0.568 & 3.48 & 0.566 & 3.36 & .573 \\
\hline S18 & $\begin{array}{l}\text { Internship programme is one of the pre- } \\
\text { requisites to obtain my certificate }\end{array}$ & 3.10 & 0.413 & 3.39 & 0.496 & 3.21 & .468 \\
\hline
\end{tabular}

Note: $\mathrm{BAC}=$ Bachelor in Accounting; BBA = Bachelor of Business Administration. S.D = Standard Deviation

For the third dimension (Soft skills), BAC students choose S13 "The internship experiences will help me to improve my personal confidence and self-esteem" (Mean $=3.57$ ), while BBA students choose S12 "The internship experience will help me to develop my interpersonal skill' (Mean $=3.76$ ) as the most important 
item. As for the overall score, both BBA and BAC students choose S11 "The internship experiences will help me to develop my communication skill" (Mean $=3.62$ ) as the most important item. In terms of dimension 4 (Monetary and Non-Monetary Incentives), BAC students choose S15 "The internship programme is able to give me the opportunity to work in a team" (Mean $=3.35$ ) while BBA students choose S17 "The internship attachment is able to give me to build up rapport and networking with people in the industry and business arena" (Mean $=3.36$ ) as the most important item. Overall scores show that both BBA and BAC students choose S17 "The internship attachment is able to give me the opportunity to build up rapport and networking with people in the industry and business arena" (Mean $=3.36$ ), as the most important item.

Table 3 presents the summary of the responses based on the four dimensions. The results show that BAC students rank Career as the most important dimension whereas BBA students rank Soft Skills as the most important dimension. For the overall scores, the results indicate that both Career and Soft Skills are important (Mean $=3.44$ ). This contradicts to the findings by Muhammad et. al. (2009) who found that the attachment failed to improve interns' interpersonal skills. On the other hand, our study supports Divine et. al. (2006). Thus we can conclude that Career and Soft Skills are important to the students when they are asked about their opinions on the industrial internship programme. Knowledge and Practical Experience and Monetary and Non-Monetary Incentives are ranked $3^{\text {rd }}$ and $4^{\text {th }}$ respectively.

Table 3: Summary of Responses by Dimensions

\begin{tabular}{llcccccc}
\hline No. & Dimensions & \multicolumn{2}{c}{ BAC } & \multicolumn{2}{c}{ BBA } & \multicolumn{2}{c}{ Overall Scores } \\
\cline { 3 - 7 } & & Mean & S.D & Mean & S.D & Mean & S.D \\
\hline 1 & Career & 3.52 & 0.365 & 3.32 & 0.366 & 3.44 & 0.376 \\
2 & Knowledge and Practical Experience & 3.26 & 0.402 & 3.17 & 0.413 & 3.22 & 0.406 \\
3 & Soft Skills & 3.39 & 0.390 & 3.52 & 0.326 & 3.44 & 0.370 \\
4 & Monetary and Non Monetary Incentives & 3.17 & 0.383 & 3.12 & 0.386 & 3.15 & 0.382 \\
\hline
\end{tabular}

Students' perceptions in internship programme by course and gender: Pearson one-way analysis of variance (ANOVA) is performed to test whether the mean of the students' perceptions differ by course (BAC and $\mathrm{BBA}$ ) and gender (male and female). Table 4 presents the results. The results clearly indicate that there are no significant differences between perceptions towards internship and course (BBA, BAC) for all statements except for S3, S12, S16 and S18. As for opinions towards intenship and gender, all the statements are not significant which means that both BBA and BAC students regardless of gender have the same same perceptions towards industrial internship programme .

Table 4: Students' perceptions in internship programme by course and gender

\begin{tabular}{|c|c|c|c|c|c|}
\hline \multirow[t]{2}{*}{ No } & \multirow[t]{2}{*}{ Items } & \multicolumn{2}{|c|}{ Course } & \multicolumn{2}{|c|}{ Gender } \\
\hline & & $\chi^{2}$ & sig. & $\chi^{2}$ & sig \\
\hline S1 & $\begin{array}{l}\text { The internship experience is able to prepare me to be a better } \\
\text { employee in the future }\end{array}$ & 6.992 & 0.008 & 0.061 & 0.805 \\
\hline S2 & $\begin{array}{l}\text { The internship experience provides me with the relevant } \\
\text { knowledge and practical experience to assist me in adapting myself } \\
\text { to my future working environment }\end{array}$ & 0.174 & 0.677 & 0.015 & 0.902 \\
\hline S3 & $\begin{array}{l}\text { The internship programme will provide me with the necessary } \\
\text { information and experiences to choose the right career path upon } \\
\text { graduation }\end{array}$ & 7.556 & $\begin{array}{l}0.023 \\
*\end{array}$ & 0.936 & 0.626 \\
\hline S4 & $\begin{array}{l}\text { The internship programme will provide me with the necessary job } \\
\text { experience that can improve my chances to get a good job upon } \\
\text { graduation }\end{array}$ & 5.788 & 0.055 & 1.430 & 0.489 \\
\hline S5 & $\begin{array}{l}\text { The internship experience will help me to relate the theories } \\
\text { learned in the classroom to the work environment }\end{array}$ & 2.374 & 0.305 & 5.393 & 0.067 \\
\hline S6 & $\begin{array}{l}\text { The internship experiences reinforce the knowledge I gain in the } \\
\text { classroom }\end{array}$ & 2.945 & 0.229 & 3.168 & 0.205 \\
\hline S7 & $\begin{array}{l}\text { The internship experiences help make my educational experiences } \\
\text { more relevant }\end{array}$ & 0.961 & 0.618 & 1.970 & 0.373 \\
\hline
\end{tabular}




\section{Table- 4 Continue}

S8 The internship experience is able to expose me to the latest technology adopted in the work place

\begin{tabular}{llll}
5.289 & 0.071 & 0.554 & 0.758 \\
0.709 & 0.702 & 1.585 & 0.453 \\
3.408 & 0.065 & 1.511 & 0.219 \\
& & & \\
2.700 & 0.100 & 0.028 & 0.867 \\
7.690 & $0.006^{*}$ & 0.818 & 0.366 \\
0.382 & 0.537 & 0.002 & 0.967 \\
0.552 & 0.759 & 4.419 & 0.110 \\
2.246 & 0.325 & 0.676 & 0.713 \\
11.51 & $0.009^{*}$ & 3.130 & 0.372 \\
2.838 & 0.242 & 3.181 & 0.204 \\
& & & \\
8.122 & $0.017^{*}$ & 1.521 & 0.468 \\
\hline
\end{tabular}

S9 Internship programme helps me to be physically and mentally fit

S10 The internship experiences will help me to develop my problem solving skill

S11 The internship experiences will help me to develop my communication skill

S12 The internship experiences will help me to develop my interpersonal skill

S13 The internship experiences will help me to improve my personal confidence and self-esteem

S14 The internship programme will help me improve my English

S15 The internship programme is able to give me the opportunity to work in a team

S16 The internship programme is able to give me the opportunity to earn some money

S17 The internship programme is able to give me the opportunity to build up rapport and networking with people in the industry and business arena

S18 Internship programme is one of the pre-requisites to obtain my certificate

Note: * Significant at the 5 percent level.

\section{Conclusion}

This study was carried out to investigate the perceptions of business and accounting students towards industrial internship programme. Outcomes from this study are important for us to have an overview of the perceptions of undergraduate students regarding industrial internship programme. The findings showed that BAC students ranked Career as the most important dimension wheareas BBA students ranked Soft Skills as the most important. For the overall scores, the results indicate that both Career and Soft Skills are important (Mean $=3.44)$. Thus in this study we can conclude that Career and Soft Skills are important to the students when they were asked about their opinions of the internship programme. Knowledge and Practical Experience and Monetary and Non Monetary Incentives are ranked $3^{\text {rd }}$ and $4^{\text {th }}$ respectively. The findings also showed that in general there were no significant differences in terms of perceptions of both business and accounting students towards internship programme by course and also gender. This research is without its limitations. Further research should be done to take into account the perceptions of other students from different courses and should cover a wider area for example other higher learning institutions. Further, the perceptions from the potential employers are also important to consider in future research.

\section{References}

Abdul-Karim, Z. A. (2009). Measuring the success of industrial internship programme for undergraduate study. International Engineering Education Conference, Madinah, Kingdom of Saudi Arabia, 16-19 May.

Cannon, J. A., \& Arnold, M. J. (1998). Student expectations of collegiate internship program in business: A 10year update. Journal of Education for Business, 73(4), 202-205.

Divine, R., Miller, R., \& Wilson, J. H. (2006). Analysis of students performance in an internship program in a U.S. University. International Journal of Quality and Productivity Management, 6(1), 1-14.

Dunaway, D. M., Bird, J., Flowers, C., \& Lyons, J. E., (2010). Interns and mentor perceptions of the internship experience. The Online Journal, 8 (3). Available at SSRN: http//: www.academicleadership.org.

Furco, A. (1996). Service-Learning: A Balance Approach to Experiential Education. Expanding Boundaries: Service and Learning. Washington DC: Corporation for National Service, 9-18.

Hauck, A. J., Allen, S. Y., \& Rondinelli, F. (2000). Impact of structured internship programmes on students performance in construction management curricula. Journal of Construction Education, 5(3), 272-287. 
Knouse, S. B., \& Fontenot, G. (2008). Benefits of the business college internship: a research review. Journal of Employment Counseling, 45, 61-66.

Moore, D., Moore, M. A. \& Plugge, P. W. (2006). Industry Perceptions and Expectations: Implications for Construction Management Internships, ASC Proceedings of the $42^{\text {nd }}$ Annual Conference, Colarado state University Fort Collins, Colorado, April 20-22.

Muhammad, R., Yahya, Y., Shahimi, S., \& Mahzan, S. (2009). Undergraduate internship attachement in accounting: the interns perspective. International Education Studies, 2(4), 49-53. 